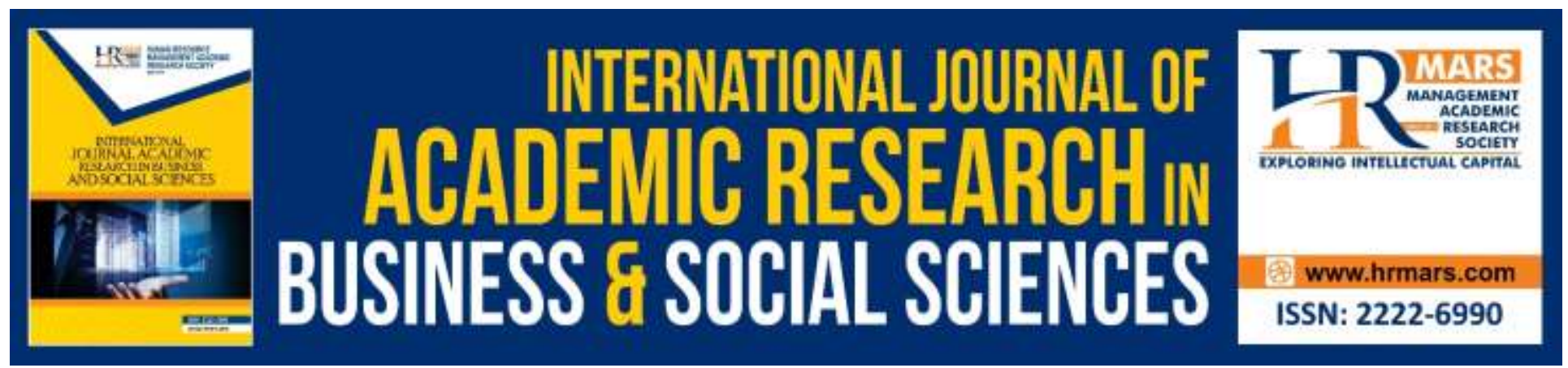

\title{
Technology Usage and Organizational Performance in the Medium Sized Manufacturing Enterprises: Does Network Competence Matter?
}

\author{
Kingsley Eze Ezuma, Siti Raba'ah Hamzah, Ismi Arif Ismail \& Abdul Lateef \\ Krauss Abdullah
}

To Link this Article: http://dx.doi.org/10.6007/IJARBSS/v9-i10/6509

DOI: 10.6007/IJARBSS/v9-i10/6509

Received: 21 September 2019, Revised: 01 October 2019, Accepted: 16 October 2019

Published Online: 31 October 2019

In-Text Citation: (Ezuma, Hamzah, Ismail, \& Abdullah, 2019)

To Cite this Article: Ezuma, K. E., Hamzah, S. R., Ismail, I. A., \& Abdullah, A. L. K. (2019). Technology Usage and Organizational Performance in the Medium Sized Manufacturing Enterprises: Does Network Competence Matter. International Journal of Academic Research in Business and Social Sciences, 9(10), 336-355.

Copyright: (C) 2019 The Author(s)

Published by Human Resource Management Academic Research Society (www.hrmars.com)

This article is published under the Creative Commons Attribution (CC BY 4.0) license. Anyone may reproduce, distribute, translate and create derivative works of this article (for both commercial and non-commercial purposes), subject to full attribution to the original publication and authors. The full terms of this license may be seen

at: http://creativecommons.org/licences/by/4.0/legalcode

Vol. 9, No. 10, 2019, Pg. 336 - 355

http://hrmars.com/index.php/pages/detail/IJARBSS

JOURNAL HOMEPAGE

Full Terms \& Conditions of access and use can be found at http://hrmars.com/index.php/pages/detail/publication-ethics 


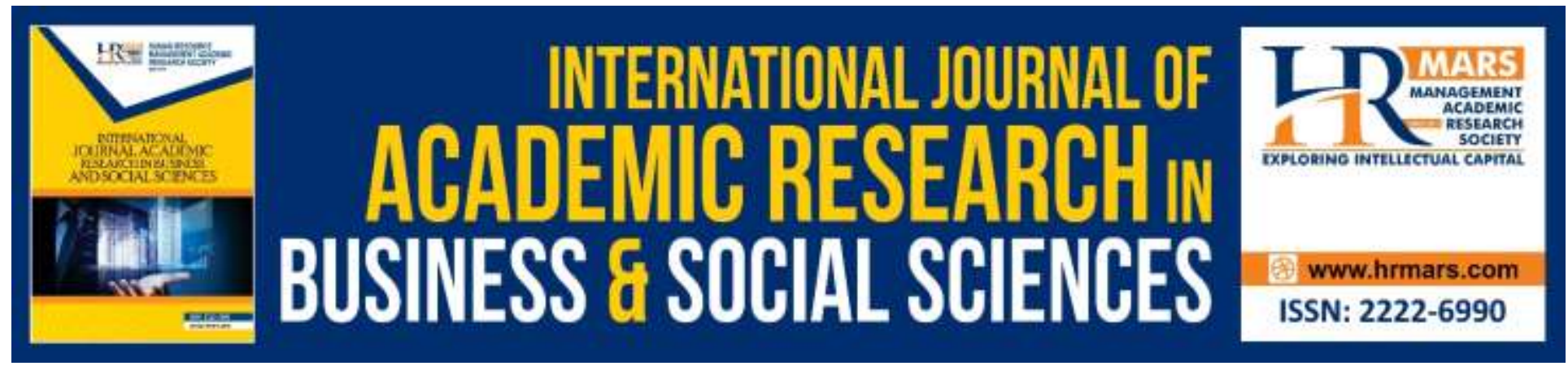

\title{
Technology Usage and Organizational Performance in the Medium Sized Manufacturing Enterprises: Does Network Competence Matter?
}

\author{
Kingsley Eze Ezuma, Siti Raba'ah Hamzah, Ismi Arif Ismail \& \\ Abdul Lateef Krauss Abdullah \\ Department of Professional Development and Continuing Education, Faculty of Educational \\ Studies, Universiti Putra Malaysia, 43400 UPM, Serdang Selangor
}

\begin{abstract}
The main objective of this paper is to determine whether network competence matters in the relationship between technology usage and organizational performance of medium-sized manufacturing enterprises in the state of Lagos, Nigeria. This study examines the conceptual relationships in the Nigerian context. The data for the study were based on the responses to structured questionnaires that were completed by 245 owners/managers of medium sized manufacturing enterprises. The Statistical Package for Social Sciences (SPSS) was used for descriptive analysis (mean values, frequencies and percentages), and Structural Equation Modelling (SEM) using AMOS was employed for inferential statistics. Furthermore, the mediating effect was examined using bootstrapping analysis. HRD indicators for performance (namely effectiveness, efficiency, development, satisfaction, innovation, and quality) were used to measure organizational performance. The findings showed that the integration of network competence practices and technology usage did translate to improved organizational performance. Network competence served to promote a degree of trust within and outside interdependent firms. Furthermore, practices related to development of the individual's skills in technology usage should be adopted to improve organizational performance. The findings indicated that network competence partially mediated the relationship between technology usage and organizational performance of medium-sized manufacturing enterprises. The findings would help Nigerian owners/managers involved in medium-sized manufacturing enterprises adopt the right human resource development practices, including the development of technology usage skills and network competence capabilities.

Keywords: Technology Usage, Network Competence, Organizational Performance, MediumSized Manufacturing Enterprises, SMES, Nigeria
\end{abstract}




\section{Introduction}

Technology usage can be defined as the extent to which technology tools are used to achieve or create value to benefit the individual, group or the organization that has the propensity to adopt technology (Dewett and Jones, 2001). Organizations use technology to facilitate work, making it easier and faster, as well as to improve competitiveness and innovativeness (Tidd, Bessant and Pavitt, 2005). Studies have also shown that technology usage in organizations, especially those in manufacturing, yields much more finished products. The result is increased profits, the amount of which depends on the level of adoption and sophistication (Hayes, Wheelwright and Clark, 1988). This implies that technology usage requires developing skills and expertise to use technology to enhance production, and as such, the importance of technology usage cannot be over emphasized, specifically in medium-sized manufacturing enterprises (Shipton, Dawson, West and Patterson, 2002). Network competence, on the other hand, is a relational competence which requires that firms adopt a networking managerial mind-set to build strategic advantage (Chaudhuria and Boerb, 2016).

In other words, organizations that lack initial human resource development (HRD) concerns for improved performance or specialized skills such as network task competences, knowledge to enhance creativity at the early developmental stages are likely to die off even after high growth (Asah et al., 2015; Sheehan and Shanahan, 2017; Siepel, et al., 2017). Therefore, encouraging owners/managers of small and medium enterprise organizations to adopt practices linked with human capital development could help improve employees' performance competencies, and ultimately improve organizational performance of the enterprise (Alagaraja, 2012; Olatunji, 2013; Swanson and Holton, 2010).

Felício, Couto and Caiado (2014) use the human capital theory and social capital theory to explain organizational performance in SMEs. Katou (2009) espouses the use of resource-based view, HRD performance linkage model, as well as casual path ways model of HRD to explain organizational performance. In the same vein, Seleim, Ashour and Bontis, (2007) use a resource-based view, knowledge-based view, and the human capital theory to explain human capital and organizational performance, while Khalique et al., (2013) adopt the intellectual capital theory to explain the impact of intellectual capital management on the performance of SMEs. Mitrega et al. (2017) use the resource-based view of the firm and the relational view of the firm (Dyer and Singh, 1998) to elucidate networking capability in supplier relationships and its impact on product innovation and firm performance. Furthermore, in a related study, Human and Naudé (2009), used the resource-based theory to explore interrelationships of network competence, network capability, and firm performance. Gamage (2007) makes use of theories which include the human capital theory, resource-based theory and behavioral theory to explain the impact of HRD on SMEs business performance. The resource-based theory was also used in a previous study on networking capability and network competence (Human and Naudé, 2009). Likewise, this study is aimed at investigating the mediating effect of network competence in the interrelationships of technology usage, human capital, and organizational performance. 
This study makes use of human capital and resource-based theories because they offer explanations for network competence. The development of knowledge, skills and competencies through educational training and experience are organizational resources that can improve organizational performance. To date, there is yet any study investigating the impact of network competence on the interrelationships of technology usage, human capital and organizational performance of medium-sized enterprises in Nigeria. Therefore, the aim of this study is to bridge this gap in knowledge for the enhancement of SMEs performance, particularly in Nigeria's manufacturing industrial sector by examining how network competence could influence organizational performance.

In this study, we carried out an empirical investigation of the factors linked to organizational performance of medium-sized manufacturing enterprises, and discuss the rationale for picking the selected variables. This study will fill the research gap by highlighting the human capital predictors, namely technology usage and network competence, to strategically improve organizational performance of medium-sized manufacturing enterprises.

\section{Organizational Performance}

In the literature of human resource development, substantial attention has been paid to the understanding of practices that can boost organizational performance (Alagaraja, 2012; Katou, 2009). Studies have also been conducted to examine factors that contribute to non-performance and failures of companies in emerging nations (Mahmud and Hilmi, 2014; Ogunyomi and Bruning, 2015). There is general consensus that organizational performance is linked to different areas of discipline such as economics, sociology, psychology, industrial engineering, human resource management and so on (Swanson and Holton, 2010). Organizational performance in each of these fields of studies is measured differently because each discipline uses a particular indicator and concept consideration to define performance or performance improvement according to a specific need or purpose. Thus, specific HRD looks at various domains of performance and the analysis is from the angle of levels attained in the organization, process, individuals and various measures of output in terms of quantity, time and quality features (Swanson, 1994; cited in Swanson and Holton, 2010). Hence, organizational performance can be conceptualized as the level at which the firm effectively meets its planned objectives through efficient utilization of its fewest available resources, together with the development of its capacity to meet future opportunities and challenges to satisfy the stakeholder needs, as well as innovation of quality products. Organizational performance is thus an important concern of both SMEs and large organizations because it reflects the extent to which their mission, vision and goal statements are achieved (Ogunyomi \& Bruning, 2015).

\section{Small and Medium Enterprise (SMEs)}

SMEs are small and medium-sized businesses with employee numbers that fall within certain limits. Holmes and Farrill (2005) refer to SMEs as enterprises with not more than 200 employees. According to Asah et al. (2015), SMEs are characterized by their ability to respond quickly to changing market conditions and challenges. Currently in Africa, SMEs comprise over $90 \%$ of 
African business operations and contribute to more than $50 \%$ of African employment and the Gross Domestic product (GDP) (Saravanan, Gupta, and Ghatak, 2008). In Nigeria, SMEs play a significant role in the development of the nation's economy. They provide over $90 \%$ of the country's employment opportunities, which essentially account for about $70 \%$ of aggregate employment created per annum, particularly in the manufacturing sector (Agwu, 2014). However, despite the critical role of SMEs as drivers of socio-economic activities (e.g. innovation, economic growth and employment generation), many owners/managers appear to be complacent in the running of their ventures, not paying much attention to issues related to skill development in order to enhance organizational performance. There is, therefore, an urgent need for an effective network competence strategy to improve performance as traditional networking is not competency driven, and as such, may be obsolete (Torkkili et al., 2015). Table 1 shows the classification of SMEs in Nigeria.

Table 1: Classification of SMEs based on Dual criteria (SMEDAN, 2013)

\begin{tabular}{lll}
\hline Size & No. of employees & $\begin{array}{l}\text { Total capital base excluding land \& } \\
\text { buildings }\end{array}$ \\
Micro & $1-9$ & $\begin{array}{l}\text { Less than } 5 \text { million Naira } \\
\text { Small }\end{array}$ \\
Medium & $10-49$ & $5-50$ million Naira \\
Large & $50-199$ & $50-500$ million Naira \\
\hline
\end{tabular}

Source: micro, small and medium enterprises (SMEDAN, 2013)

Although SMEs are sectored along manufacturing, marketing services and other forms of businesses, this study focused only on medium-sized manufacturing enterprises in Lagos state, Nigeria, because they are the most widespread, with the highest number of employees as well as contribution to GDP and exports, as compared to other SMEs based on the employment criterion (SMEDAN, 2013).

\section{Technology Usage}

Technology usage refers to the use of technical or technological skills, knowledge and expertise to operate and manage technologically-driven apparatus. It could be machines, robots, computer, software or information communication technology (ICT) (Brynjolfsson and McAfee, 2014). Individuals or organizations make use of technology because of its usefulness; work becomes easier and can be completed faster (Adams, Nelson and Todd, 1992). Increasing competition in the manufacturing sector demands that employees acquire technology usage skills and expertise to improve organizational performance. It is generally agreed that individuals and organizations without technology usage skills or expertise cannot be relevant or competitive in today's consortium of knowledge-driven enterprises. Specialized human resources and heterogeneous assets of organizations should keep in pace with advances in science and technological knowledge for the purpose of creating and capturing value (Bailetti, 2012; Spiegel and Marxt, 2011). This is critical to organizational performance, especially in the manufacturing 
industries, where robots, machines and ICT can play a major role in high tech production (Bahrin, Othman, Azli, and Talib, 2016). In addition, expertise in technology usage strengthens and confirms its usefulness in terms of ease, speed and innovativeness, thus providing an edge for product differentiation and competitiveness (Ratinho, Harms, and Walsh, 2015).

\section{Network Competence}

Network competence has to do with the degree of network management and task performance. It is a mechanism for knowledge collaboration and relationship building (Chaudhuri and Boer, 2016; Torkkeli, Kuivalainen, Saarenketo and Puumalainen, 2016). Ritter (1999) define network competence as the degree of skills, knowledge, and capability required to perform or execute the relationship building task of interdependent firms. Enterprises collaborate in order to consolidate each other's strength to succeed, confirming the notion that firms can no longer grow in isolation as they cannot, by themselves, produce the needed skill and knowledge base to improve performance (Jagongo and Kinyua, 2013). Hence, using the network competence approach in businesses could bridge both knowledge and marketing gaps across geographical boundaries. In this sense, captains of industries can explore the benefits of network competence by institutionalizing innovations and technical training in their organizations to develop qualified managers who can handle technical and innovative collaboration in order to promote efficiency (Bager et al., 2015). This shows that firms that are able to develop and manage their networks have a better chance of growing their businesses successfully than those that do not apply network competence (Chaudhuri and Boer, 2016; Chen, 2015; Torkkeli et al., 2016). In addition, it is also thought that the application of network competence in work and inter organizational collaboration can lead positively to enterprise performance.

\section{Theorizing Organizational Performance of Medium-Sized Enterprises}

The theory chosen to explain the link between technology usage, organizational performance and network competence is the resource-based theory. This theory takes into account both tangible and intangible resources of an organization. Tangible resources are linked to the structural content of the organization while the intangible resources are the skilled workforce of the organization. Within the framework of the resource-based theory, Barney et al. (2001) and Wernerfelt (1984), as cited in Miles (2012), explain how organizations compete against one another on the basis of their resource capabilities.

It is the desire of every organization to create and develop a unique resource which cannot be easily duplicated by rivals or competing organizations (Barney et al., 2001). The answer lies in the development of skilled human resources to provide the firm with a unique and sustainable competitive edge. Hence it is important to ensure proper development of the firm's human resources by facilitating the development of competencies that are unique and enterprise specific to generate tactic enterprise knowledge, skills and capabilities. Taken together, the resource-based theory looks at developed technology usage skills as well as network competence skills as intangible assets, while structures such as technology-driven machinery, robots and ICT 
apparatus or firm other properties are tangible assets acquired to increase production activities (Miles 2012).

In this study, the resource-based theory explains the influence of the relationship between technology usage and network competence capabilities on organizational performance from the perspective of intangible resources in medium-sized manufacturing enterprises.

\section{Relationship between Technology Usage and Network Competence}

A study has shown that the generic trust of organizations over the years and currently across the global space is embedded in the use of technology There is hardly any organization that exists today that does not make use of technology (Smallbone et al., 2000). Technology usage in manufacturing has been shown to increase productivity while lowering the cost of production; the finished products are refined and of high quality; there is precision in efficiency through the use of computers, machines, ICT, robots etc. (Smallbone et al., 2000).

Network competence, on the other hand, is linked to business plans that strategize to coordinate through initiation and utilization of enterprise relationships, with attention focused on particular areas of collaboration that could be of interest or benefit to prospective partners (Mitrega et al., 2012; Thornton et al., 2014). Despite the challenge of clarity in defining specific areas to network, firms can, through interaction with others in related businesses, develop a clear understanding of unexplored areas to network.

Network competence is, however, different from other network related capabilities because it involves dyadic and network-level organizational ability, which includes task execution activities (requiring, for example, organizational competence) as well as social and specialist qualifications which have to do with individual competence of the employees involved in the network collaboration (Mitrega et al., 2012; Torkkeli et al., 2016). Building on the above understanding, the alignment of network competence and technology usage could ensure the firm's success; it is a strategy for sensing and attracting good business opportunities. Hence, the importance of developing a competitive edge over other firms via skilled human capital cannot be over emphasized (Chaudhuri and Boer, 2016 and Chell, 2013). The following hypothesis is thus formulated:

H1. There is a positive relationship between technology usage and network competence in medium-sized manufacturing SMEs.

\section{Relationship between Technology Usage and Organizational Performance}

Entrepreneurs who venture into business need to assemble and deploy specialized human resources and heterogeneous assets in line with science and technological knowledge so as to create and capture value (Bailetti, 2012; Spiegel and Marxt, 2011). Technology usage in SMEs and other fields of human endeavor has become the ultimate concern of the new global order, especially in the manufacturing industries where robots, technology tools and ICT play a major role in ensuring high tech productivity at reduced costs. According to Poutziouris et al. (2002), 
usage of technology in manufacturing helps assure that goods are delivered speedily and more cheaply, thus accelerating business performance across social and manufacturing boundaries. SMEs have identified technology usage as an edge for product differentiation and competitive advantage, both of which are vital to enterprise development (Aasheim et al., 2009). Captains of industries and top management leaders in small and large businesses make use of technology to create, capture and deliver value to their stake holders (Ratinho et al., 2015). Usage of technology in SMEs is linked to three basic dimensions, viz. (i) competitive advantage which is linked to the identification of technological possibilities (Schumpeter, 1912; cited in Ratinho et al., 2015), (ii) capacity to decrease business costs through the use of technology, and (iii) product model shift through the use of new technology as a remedy to bridge market gaps (Ratinho et al., 2015).

The work of Schumpeter (1912 and 1942) has been identified by researchers as the oldest foundational pillars on which SME technology emanates (Ratinho et al., 2015). In his theory of creative disruption, Schumpeter identified SME drive as central to any economic growth. This finding of Schumpeter has pioneered the development of creative advantage which is in line with emerging technology in the industrial sector, as well as bridge the existing market gap (Groen and Walsh, 2013; Sodri et al., 2012). Based on the above understanding, managers of SMEs should learn how to make use of new technology to increase productivity, create value, and improve organizational performance (Martín-Rojas, García-Morales, and Bolívar-Ramos, 2013). It is, therefore, hypothesized:

$\mathrm{H} 2$. There is a positive relationship between technology usage and organizational performance of mid-sized manufacturing SMEs.

\section{Mediating effect of Network Competence on Organizational Performance}

The mediating role of network competence has yet to be investigated in great depth in previous research. There are, however, related studies on network competence in the literature. For example, Ritter (1999) examines some organizations that focus on product and process development activities. His empirical study shows the importance of collaboration with firms in related businesses. Thus, he postulates how a particular skill could be identified and used to manage the company's network needs and relationship-building in a specialized manner. Elsewhere, Torkkeli et al. (2016) examine how network competence is related to the growth of domestic and international SMEs in the Nordic region.

Network competence refers to a set of complex dynamic capabilities that enable organizations to shape their relationships with external partners, thereby optimizing different portfolios of business relationships and re-allocating important resources such as time, investments and technical competences from one business relationship to another (Mitrega, Forkmann, Ramos and Henneberg, 2012). To the best of the researcher's knowledge, no study has been conducted on the mediating effect of network competence on organizational performance of medium-sized manufacturing enterprises (SMEs) in Nigeria. This gap in the literature is a serious setback to the development of theories and tools for monitoring the performance of SMEs. Therefore, to bridge 
INTERNATIONAL JOURNAL OF ACADEMIC RESEARCH IN BUSINESS AND SOCIAL SCIENCES Vol. 9, No. 10, October, 2019, E-ISSN: 2222-6990 @ 2019 HRMARS

the information gap, this research is conducted to investigate network competence as a mediator on organizational performance of medium-sized manufacturing SMEs. It is, therefore, hypothesized:

H3: Network competence mediates the relationship between technology usage and organizational performance.

\section{Methodology/Procedure}

The reachable population to this study was limited to owners/managers of medium-sized manufacturing enterprises in Lagos state, Nigeria. Lagos was chosen because the state had the highest number of medium- sized manufacturing enterprises in Nigeria (SMEDAN, 2013). This research utilized the simple random probability sampling technique whereby everyone in the population under study had equal chances of being selected. The total number of registered medium-sized manufacturing enterprises in Lagos, according to SMEDAN, 2013, was 619 (N population). Using the Yamane formula (1967), the calculated sample size outcome of the medium sized enterprises should be 242.9 , or approximately 243 . A table of random numbers was used to select 243 participants. Meanwhile, an extra $10 \%$ was added to the total sample, just in case there were incomplete or unreturned questionnaires (Singh and Masuku, 2013). Having decided on the sample size, a total of 267 questionnaires were distributed to the randomly selected owners/managers of medium-sized manufacturing enterprises in Lagos. When 258 questionnaires were returned, they were subjected to exploratory data analysis (EDA); 245 responses were correctly answered or had complete valid cases, representing 91.8 percent, thus, the actual sample size used for the study analysis was 245.

The main tool of data collection for this study was a questionnaire which had been specially developed to gather relevant information. The questionnaire consisted of seven sections. Sections $A$ and $B$ contained items on demographic characteristics and general information about the business. Items in Section $C$ required respondents to give information pertaining to organizational performance, the dependent variable in the study.

\section{Assessment of Organizational Performance}

To measure organizational performance, this study used an instrument developed by Katou (2009), a five-point Likert type scale consisting of six dimensions of organizational performance, viz. efficiency, effectiveness, development, satisfaction, innovation, and quality. Of the 25 items in Section C, Items 1-5 required respondents to indicate how effective their strategies were in meeting the firm's goals (e.g. How effective are the strategies aligned to the mission and goal statement of my enterprise?). Items 6-9 were about the respondent's effort to efficiently maximize the fewest resources to achieve the objectives of the firm (e.g. My enterprise utilized the fewest resources to meet its objectives). Items 10-13 were concerned with general norms about the effect of training and development on improving individuals' capacity to perform well (e.g. My employees' skills are developed for current and future challenges and opportunities). Items 14-16 dealt with the extent to which stakeholders of the firm were satisfied (e.g. My 
organization pays attention to stakeholder's needs). Items 17-19 solicited information about how much emphasis the firm placed on new product creation or development (e.g. My organization places much emphasis on the development of new products and services). Items 20-25 were related to the respondent's ability to deliver quality-manufactured products (e.g. My organization engages employees to deliver products without error). The scale coefficient $\alpha$ for the composite organizational performance measure was 0.9 .

\section{Assessment of Network Competence}

In Section D, the 15 items related to general network competence were based on a previous researcher's questionnaire (Ritter et al., 2002; Torkkeli et al., 2016, 2012). In this study, the network competence items were measured through a five-point Likert scale. In items 26-30, respondents were asked about collaboration with other partners (e.g. I initiate meetings and discussions with those in our firm involved in relationships with our partners). Items 31-35 assessed the extent to which relationships between partners had improved their organizations' objectives (e.g. I monitor the extent to which the relationship with our partners work to our advantage). Items 36-40 were linked to the sharing of vital and confidential information among integrating partners (e.g. I exchange confidential information with our partners). The scale coefficient $\alpha$ for the composite network competence measure was 0.86 .

\section{Assessment of Technology Usage}

The Technological pedagogical content knowledge scale (TPCKS) as validated by Hosseini and Kamal (2012) uses a five-point Likert type scale with 33 items. The items were related to general knowledge about technology usage (e.g. I can use technology to develop strategies for solving production problems). Items 91-98 were related to using technology to enhance production activities and manage business activities (e.g. I can choose technologies that will enhance my manufacturing approaches). Items 99-102 were concerned with using technology to evaluate, access information, and facilitate collaboration (e.g. I can evaluate and select new information resources and technological innovations based on their appropriateness to specific tasks for my enterprise). The scale coefficient $\alpha$ for the composite technology usage measure was 0.95 .

\section{Results/ Measurement Model Validation}

Confirmatory Factor Analysis (CFA) was conducted to examine the construct validity, which is the extent to which a set of measured items reflects the theoretical latent construct that it is designed to measure (Hair et al., 2006). First order CFA was conducted to assess measurement of factor loading for items; items with factor loading lower than 0.5 were dropped. Second order CFA was conducted where convergent and discriminant validity were examined to test the validity of each construct. Meanwhile, the criteria for fit indices to test for a model fit according to Hair et al., (2010) were as follows: chi-square (CMIN $x^{2}=(100-200)$; CAMIN/DF $=X^{2} / D F:$ GFI= $>.90 ; \mathrm{CFI}=>.90 ; \mathrm{IFI}=>.90 ; \mathrm{TLI}=>.90 ; \mathrm{RMSEA}=<.08$. The CFA supported our hypothesized threefactor structure for the study variables based on the model fitness $=x^{2}(141)=250.622 ; \mathrm{P}>=0.05$; $=.000 x^{2} / \mathrm{DF}=1.777 ; \mathrm{GFI}=.904 ; \mathrm{CFI}=.977 ; \mathrm{IFI}=.977 ; \mathrm{TLI}=.972 ; \mathrm{RMSEA}=.056$. The results of our CFA provided empirical evidence of the validity of the three constructs. Composite reliability and 
Average Variance Extracted (AVE) and results indicated that all the constructs possessed highinternal consistency and were within the acceptable range. Table 2 shows the summary results of the Construct Validity (CR) above .7 and the AVE value of .5 and above, in line with the recommended values (Bagozzi and Yi, 2012; Hair et al., 2014).

Table 2: Construct validity (AVE and CR) and Item factor loading Final CFA Fitted Measurement Model of the study

\begin{tabular}{lll}
\hline Variables & C.R & AVE \\
\hline Technology usage & 0.947 & 0.580 \\
Organizational Performance & 0.924 & 0.674 \\
Network Competence & 0.859 & 0.753 \\
\hline
\end{tabular}

Note: $C R$ = Construct/composite reliability; $A V E=$ Average Variance Extracted;

CFA= confirmatory factor analysis.

The discriminate validity of the constructs was determined by examining whether the AVE for each construct was greater than the squared correlations (shared variance) between the construct and all other constructs in the model (Hair et al., 2006). Discriminate validity is established if the AVE of a pair of constructs is greater than their squared correlation coefficient (Farrel, 2010). As shown in Table 3 below, the assumption for discriminate validity was not violated as the constructs were distinct from one another.

Table 3: the study constructs AVE, Correlations and squared correlation

\begin{tabular}{llll}
\hline Variables & TECH & OP & NC \\
\hline Technology usage & $\mathbf{0 . 7 6 1}$ & & \\
Organizational performance & $0.584^{* * *}$ & $\mathbf{0 . 8 2 1}$ & \\
Network competence & $0.467^{* * *}$ & $0.750^{* * *}$ & $\mathbf{0 . 8 6 8}$ \\
\hline
\end{tabular}

Note: $\mathrm{AVE}=$ Square root of Average Variance Extracted are the values in bold while the starred values $(* * *$ significant level) are correlations among variables. $\mathrm{TECH}=$ Technology usage, $\mathrm{O} p=$ Organization performance, $\mathrm{NC}=$ Network competence

\section{Findings}

As shown in Table 4, 77.6\% of the respondents who were owners/managers of medium-sized manufacturing enterprises were males, while only $22.4 \%$ were females. The much lower percentage of female owners/managers may be attributed to their cultural background as well as their role in taking care of the home and children. It may also be linked to the fact that certain business environments are less accommodative to female-owned enterprises. This confirms the findings from other scholars that males participate more in the manufacturing sector than in other sectors such as garment or food vending (Gamage, 2007; Isaga et al., 2015). 
With regard to the age of owners/managers, Table 4 shows that $21.6 \%$ were $<35$ years, $25.3 \%$ were within the age of $35-40$ years, $17.6 \%$ in the range of $41-45$ years, $15.1 \%$ were aged $46-50$ years, and $20.4 \%$ were above 50 years of age. Based on the results, those within the age bracket of 35-40 years were considered active and more productive, with a high level of reasoning, maturity, and orientation to take the risk of setting up a business, and were self-reliant. The results also indicated that $11.1 \%$ of owners/managers were singles while $81.9 \%$ were married. The rest comprised $3.3 \%$ who were separated, $1.6 \%$ divorced, and $2.1 \%$ who had lost their spouses.

With regard to the respondents' level of education, the results showed that the owners/managers possessed master's degree and above (42.4\%), diploma or basic degree (44.1\%), secondary school certificate (8.6\%) respectively. Only $2.4 \%$ of the respondents either had no education or up to primary level only. The data also showed that $91.4 \%$, of owners/managers had attended various types of training. This was contrary to previous findings. In fact, non-attendance was highlighted as the main reason for the failure of many SMEs (Mahmud and Hilma, 2014). In this study, however, the data revealed that $24.9 \%$ underwent training on how to operate manufacturing machinery, $45.7 \%$ attended trader's training, $17.6 \%$ had mechanical engineering training, $11.0 \%$ were trained as civil engineers, while $0.8 \%$ received miscellaneous types of training. The fact that $70.6 \%$ of the respondents who were into manufacturing machinery and undergone trader's training showed that many of them realized the importance of being equipped with the nitty-gritty of running a successful business, i.e. knowing when to produce more and when to cut production, taking into consideration prevailing market forces.

The next popular course was training to operate manufacturing machinery. This was followed by courses on mechanical engineering. Generally, the respondents indicated that they had attended training in areas where they believed would enhance their business performance. As for training duration, $15.5 \%$ of the respondents attended some form of training for less than one year, $34.7 \%$ underwent training for one year, $20.8 \%$ of them attended training for two years, and $19.2 \%$ signed up for training that lasted three years. Meanwhile, $9.8 \%$ of the respondents even attended training for over three years. This shows that the respondents were aware of the importance of training to improve organizational performance. Table 4 also shows that $25.7 \%$ of the businesses were between one to five years old, $53.9 \%$ six to ten years, $14.7 \%$ between eleven to fifteen years. Taken together, only $5.7 \%$ some of these firms had been in existence for well over sixteen years.

The findings also revealed that $63.8 \%$ of SMEs were founded by only one owner, $28.0 \%$ were observed to have been founded by two owners, while $8.2 \%$ were founded by three owners. This indicates that most medium-sized enterprises were mostly established by one owner. SMEDAN (2013) categorized medium-sized SMEs based on the number of employees, ranging from 50 to 199. As shown in Table 4, those with 50 to 100 employees constituted $76.3 \%$ of the total mediumsized manufacturing SMEs, followed by those with 101 to 150 employees at $18.0 \%$, while 151 to 
199 were employed in $5.7 \%$ of the medium-sized SMEs. This shows that higher concentrations of employees were evident in the medium-sized manufacturing SMEs.

Table 4: Demographics of the respondents $(n=245)$

\begin{tabular}{|c|c|c|}
\hline Demographics & Frequency & Percentage \\
\hline \multicolumn{3}{|l|}{ Gender } \\
\hline Male & 190 & 77.6 \\
\hline Female & 55 & 22.4 \\
\hline \multicolumn{3}{|l|}{ Age of owners/managers } \\
\hline$<35$ years & 53 & 21.6 \\
\hline $35-40$ years & 62 & 25.3 \\
\hline $41-45$ years & 43 & 17.6 \\
\hline $46-50$ years & 37 & 15.1 \\
\hline$>50$ years & 50 & 20.4 \\
\hline \multicolumn{3}{|l|}{ Marital Status } \\
\hline Single & 27 & 11.0 \\
\hline Married & 201 & 82.0 \\
\hline Separated & 8 & 3.3 \\
\hline Divorced & 4 & 1.6 \\
\hline Widow/widower & 5 & 2.1 \\
\hline \multicolumn{3}{|l|}{ Level of Education } \\
\hline Never attended school & 6 & 2.4 \\
\hline Primary school & 6 & 2.4 \\
\hline Secondary school & 21 & 8.6 \\
\hline Diploma /degree & 108 & 44.1 \\
\hline Master's degree and above & 104 & 42.4 \\
\hline \multicolumn{3}{|l|}{ Have you attended training } \\
\hline Yes & 223 & 91.4 \\
\hline No & 22 & 8.6 \\
\hline \multicolumn{3}{|l|}{ Type of training } \\
\hline Manufacturing machine operator & 61 & 24.9 \\
\hline Trading & 112 & 45.7 \\
\hline Mechanical engineer & 43 & 17.6 \\
\hline Civil engineer & 27 & 11.0 \\
\hline Others (specify) & 2 & .8 \\
\hline \multicolumn{3}{|l|}{ Training duration } \\
\hline$<1$ year & 38 & 15.5 \\
\hline 1 year & 85 & 34.7 \\
\hline 2 years & 51 & 20.8 \\
\hline 3 years & 47 & 19.2 \\
\hline
\end{tabular}


INTERNATIONAL JOURNAL OF ACADEMIC RESEARCH IN BUSINESS AND SOCIAL SCIENCES

Vol. 9, No. 10, October, 2019, E-ISSN: 2222-6990 @ 2019 HRMARS

\begin{tabular}{lll}
\hline Demographics & Frequency & Percentage \\
\hline >3 years & 24 & 9.8 \\
Business Establishment & & \\
1-5 years & 63 & 25.7 \\
6-10 years & 132 & 53.9 \\
$11-15$ years & 36 & 14.7 \\
Over 16 years & 14 & 5.7 \\
No of employees & & \\
$50-100$ & 187 & 76.3 \\
$101-150$ & 44 & 18.0 \\
$151-199$ & 14 & 5.7 \\
& & \\
\hline
\end{tabular}

\section{Structural Model Estimation}

Figure 1 depicts the hypothesized interrelationship of the independent variable, the dependent variable and the mediator variable.

The overall model fitness of the hypothesized structural model was assessed on the criteria for model fitness, viz. Chi-Square $=\mathrm{CMIN}\left(\mathrm{X}^{2}\right)$ value falls between 100 and 200 as recommended by Tabachnik and Fidel (1995). In the present study, the Chi-square for the hypothesized structural model was $284.362(179)$ and $P$ value $(>=0.05)=.000$. For the relative chi-square (CMIN/DF), according to Bentler (1990), the relative Chi-square DF must be $<5.0$. Therefore, in this study the relative chi-square of 1.589 was within recommended range. The GFI according to Chau (1997) must be equal or greater than 0.8 ; in this study the GFI of 0.896 was greater than the recommended threshold of 0.8. Meanwhile, CFI, IFI and TLI must be equal or greater than 0.9. In this regard, the three fit indices were greater than 0.9 (CFI=.975, $I F I=.975$, and $T L I=.970$ respectively). RMSEA, according to Byrne (2001), should be equal or less than .08 to meet criteria for model fitness. In this study the RMSEA was .049 as recommended. Taken together and based on the result of the fit indices, the hypothesized structural model for this study could be said to meet the criteria for model fitness. 


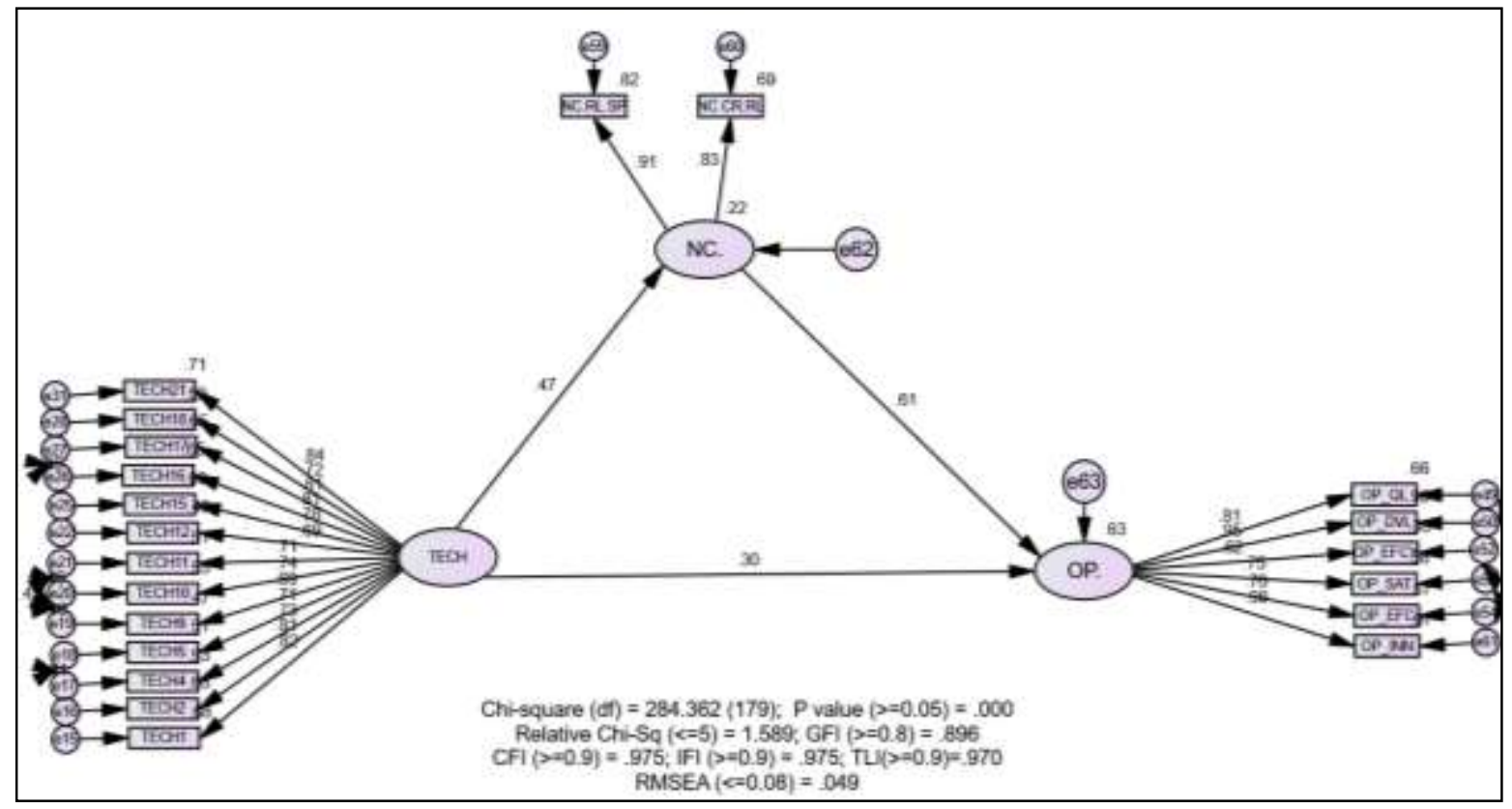

Figure 1: Structural model for the construct

Table 5 presents the path and its coefficients, indicating how much the effect of every exogenous constructs had on the respective endogenous constructs. For example, the path coefficient of technology usage to network competence was 0.404 . This value indicated that for every one unit increase in technology usage, its effect would contribute 0.404 unit increase in network competence. Consistent with the contribution applicable, technology usage had a significant positive effect on network competence $(b=.404, \rho=0.000)$. Technology usage also had a significant direct effect on organizational performance $(b=.182, \rho=.000)$. Thus, the results lent support to $\mathrm{H}_{1}$ and $\mathrm{H}_{2}$. Furthermore, the path from network competence to organizational performance was also supported $\left(b^{=} .428, \rho=.000\right)$.

Table 5: The regression path coefficient between the constructs and its significance

\begin{tabular}{llllllll}
\hline Construct & & Construct & Estimate & S.E & C.R. & P.value & Results \\
\hline NC. & $\leftarrow--$ & TECH & 0.404 & 0.059 & 6.864 & $* * *$ & Significant \\
OP & $\leftarrow--$ & TECH & 0.182 & 0.033 & 5.549 & $* * *$ & Significant \\
OP & $\leftarrow--$ & NC. & 0.428 & 0.043 & 9.892 & $* * *$ & Significant \\
\hline
\end{tabular}

Note: $\mathrm{NC}=$ Network Competence, $\mathrm{Op}=$ Organizational Performance; $\mathrm{TECH}=$ technology usage

S.E=Standardized Estimate, $C . R=$ Critical Ratio

\section{Mediation Analysis}

The direct mediation model between technology usage and organizational performance was 0.59 and it had a significant $p$-value $<0.000$. The coefficient value for the direct effect was reduced 
from 0.58 to 0.30 , but significant at 0.000 . In this case it was a partial mediation. Therefore, to test for the significant indirect effect of network competence on the relationships between technology usage and organizational performance on individual paths, findings for the total, indirect and direct effect test for mediation estimation were determined and shown in Table 6.

Table 6: Distinguishing the standardized total, direct and indirect effect of model and their P-Values

\begin{tabular}{|l|l|l|l|l|l|}
\hline & & $\begin{array}{l}\text { Total } \\
\text { effect }\end{array}$ & Direct effect & $\begin{array}{l}\text { Indirect } \\
\text { effect }\end{array}$ & Type of mediation \\
\hline \multirow{2}{*}{ TECH $\rightarrow O P$} & $\beta$ eta & 0.584 & 0.300 & 0.285 & \multirow{2}{*}{ partial mediation } \\
\cline { 2 - 5 } & P value & 0.005 & 0.005 & 0.002 & \\
\hline
\end{tabular}

The standardized regression weight of direct effect of technology usage on organizational performance of SMEs was significant $(\beta=.300, \rho=0.005)$ and the standardized indirect effect of technology usage on network competence through organizational performance of SMEs was also found to be significant $(\beta=.285, \rho=0.002$ ). The findings indicated that network competence partially mediated the relationship between technology usage and organizational performance of medium-sized manufacturing enterprises. Partial mediation occurs if the direct effect of independent variable on dependent variable is significant and when mediation enters the model, the direct effect is reduced since some of the effects have shifted through the mediator. If it is reduced but still significant the mediation effect is said to be partial mediation. Mediation suggests that the relationship between technology usage and organizational performance of SMEs is significantly improved through network competence. Hence, the study validated the supposition that network competence was a mediator in the relationship between technology usage and organizational performance of SMEs. Owing to the application of network competence, the relationship between technology usage and organizational performance was further enhanced.

\section{Bootstrapping}

In this study, bootstrapping was performed by resampling 500 bootstrap samples and bias corrected at $95 \%$ confidence interval through computation to confirm the mediation test. The results of standardized direct and indirect effects revealed that network competence partially mediated the relationship between technology usage and organizational performance of the manufacturing SMEs in Lagos. Therefore, $\mathrm{H}_{3}$ was supported by the mediation analysis, implying that technology usage had an indirect rather than direct effect on organizational performance through network competence. Using the conventional procedure according to Zainudin (2015), we compared the results of the mediation and bootstrapping, as shown in Table 7. 
INTERNATIONAL JOURNAL OF ACADEMIC RESEARCH IN BUSINESS AND SOCIAL SCIENCES Vol. 9, No. 10, October, 2019, E-ISSN: 2222-6990 @ 2019 HRMARS

Table 7: Bootstrapping results to show effects of technology usage on organizational performance

\begin{tabular}{lll}
\hline & Indirect effect & Direct effect \\
\hline Bootstrapping results & 0.285 & 0.300 \\
Bootstrapping $p$-value & 0.002 & 0.005 \\
Results & Significant & Significant \\
Type of mediation & Partial mediation since indirect is also significant \\
\hline \multicolumn{2}{c}{ Standardized total effect tech-network competence-organizational performance } \\
$=0.585 ; p<0.005$ is significant
\end{tabular}

\section{Discussion}

The findings of this research connote a step beyond previous knowledge of technology usage and innovation studies that only reported a direct linear relationship between technology usage and organizational performance. In particular, this study was able to link the indirect effect of technology usage to organizational performance through network competence. This finding contributes to the literature about the effect of network competence on technology usage in boosting organizational performance. First, as mentioned before, the findings indicated that network competence partially mediated the relationship between technology usage and organizational performance of medium-sized manufacturing enterprises. Secondly, the findings demonstrate that technology usage by employees in a firm leads it to invest and improve its network capabilities, resulting in higher organizational performance.

The findings also provide some practical implications to HRD professionals, policy makers, as well as owner/managers about the link between technology usage and network competence, about how they can translate this link into better organizational performance. Firstly, since technology usage plays a critical role in the organizational performance of medium-sized manufacturing SMEs should invest more in technology driven machines and ICT to meet innovation concerns, as well as create and apply new knowledge, leveraging on ideas to influence changes that would deliver good business value. Such investments in human capital development to enhance technology usage expertise will support creativity and innovation of quality products that can sustain organizational performance over time. Moreover, this study provides an understanding of technology usage to improve organizational performance, while placing emphasis on the strategic importance of network competence as a mediating mechanism. This suggests the greater the application and implementation of network competence capabilities by owner/managers of medium-sized manufacturing enterprises, the higher the level of organizational performance.

\section{Conclusion}

The aim of this study is to enhance the understanding of a potential mechanism, viz. network competence, through which technology usage influences organizational performance in medium-sized SMEs. The result of the study showed that there was a positive relationship 
between technology usage and network competence of owners/managers of medium-sized manufacturing SMEs; technology usage was found to have a significant positive effect on network competence ( $b=.404, \rho=0.000$ using AMOS). Also, the result showed that technology usage had a significant direct effect on organizational performance $(b=.182, \rho=.000)$. The path from network competence to organizational performance was also supported $(b=.428, \rho=0.000)$ for medium-sized manufacturing enterprises in the study area. It was also established that network competence partially mediated the relationship between technology usage and organizational performance $(\beta=.300, \rho=0.005)$. The standardized indirect effect of technology usage on network competence through organizational performance of SMEs was found to be significant ( $\beta$ $=.285 \rho=0.002$ ). Finally, it is hoped that the findings reported here, which demonstrated the intervening effect of network competence between technology usage and organizational performance, will encourage others who wish to carry out further HRD research in Nigeria, within the sub-region and beyond.

\section{Limitations and Future Research}

The findings of this study should be interpreted with consideration to the following shortcomings. The first limitation is hinged on the fact that this study focused on a locality in Nigeria; hence, diversified spectrum of sampling is encouraged. Even though the study has contributed to understanding the mediating effect of network competence on organizational performance, this finding should be treated as preliminary until future research replicates/ confirms the finding with samples from a broader range of industry and organizations, both in public and private sectors. Furthermore, the results of the current study are limited to medium-sized manufacturing enterprises in Lagos state, Nigeria, Thus, these results may not apply to micro-small and large enterprises in other parts of Nigeria and other countries. Future longitudinal and experimental study would assist to confirm or otherwise the causal paths investigated in this present study. Moreover, in this study, organizational performance was limited to that of medium-sized manufacturing SMEs. While this is a key outcome variable in most empirical studies, future research primarily within the sub-region and beyond should examine different sets of owner/managers outcome to assess organizational effectiveness and SMEs growth in other sectors of the economy, such as the non-manufacturing sector, in order to confirm the results reported in this study. Finally, future research should focus on testing the current model with other knowledge styles such as leadership styles, and its effect on organizational performance.

\section{References}

Agwu, M. O. (2014). Issues, Challengesand Prospectsof Small and Medium Scale Enterprises (SMEs) in Port-Harcourt City , 3(1), 101-114. http://doi.org/10.14207/ejsd.2014.v3n1p101

Adams, D. A., Nelson, R. R., \& Todd, P. A. (1992). Perceived usefulness, ease of use, and usage of information technology: A replication. MIS quarterly, 227-247.

Alagaraja, M. (2012). Human Resource Development Review. Sege Publications, 12((2)), 117-143. http://doi.org/10.1177/1534484312450868

Asah, F., Olufunso, O., Ellen, F., Sen, B. (2015). Article information : Economics and Management Studies, 6(3), 308-322. 
Felício, J. A., Couto, E., \& Caiado, J. (2014). Human capital, social capital and organizational performance. Management Decision, 52(2), 350-364.

Bagozzi, R. P., \& Yi, Y. (2012). Specification, evaluation, and interpretation of structural equation models. Journal of the academy of marketing science, 40(1), 8-34

Bahrin, M. A. K., Othman, M. F., Azli, N. H. N., \& Talib, M. F. (2016). Industry 4.0: A review on industrial automation and robotic. Jurnal Teknologi, 78(6-13)

Bailetti, T. (2012). Technology entrepreneurship: overview, definition, and distinctive aspects. Technology Innovation Management Review, 2(2)

Bager, T. E., Jensen, K. W., Nielsen, P. S., \& Larsen, T. A. (2015). Enrollment of SME managers to growth-oriented training programs. International Journal of Entrepreneurial Behavior \& Research, 21(4), 578-599. http://doi.org/10.1108/IJEBR-12-2014-0224

Barney, J., Wright, M., \& Ketchen, J. D. J. (2001). The resource-based view of the firm: Ten years after 1991. Journal of Management, 27(6), 625-641.

Brynjolfsson, E., \& McAfee, A. (2014). The second machine age: Work, progress, and prosperity in a time of brilliant technologies. WW Norton \& Company.

Chaudhuri, A., \& Boer, H. (2016). Journal of Engineering and Technology Management The impact of product-process complexity and new product development order winners on new product development performance: The mediating role of collaborative competence. Journal of Engineering and Technology Management, 42, 65-80. http://doi.org/10.1016/j.jengtecman.2016.10.002

Chell, E. (2013). Review of skill and the entrepreneurial process. http://doi.org/10.1108/13552551311299233

Chen, L. C. (2015). Building extra-regional networks for regional innovation systems: Taiwan's machine tool industry in China. Technological Forecasting and Social Change, 100, 107-117. http://doi.org/10.1016/j.techfore.2015.07.014

Dewett, T., \& Jones, G. R. (2001). The role of information technology in the organization: a review, model, and assessment. Journal of management, 27(3), 313-346..

Dyer, J. H., \& Singh, H. (1998). The relational view: Cooperative strategy and sources of interorganizational competitive advantage. Academy of management review, 23(4), 660679.

Gamage, A. (2007). Impact of HRD Practices on Business Performance: An empirical analysis of manufacturing SMEs in Japan. Meijo Review, 8(3), 85-109.

Groen, A. J., \& Walsh, S. T. (2013). Introduction to the field of emerging technology management. Creativity and innovation management, 22(1), 1-5.

Hayes, R. H., Wheelwright, S. C., \& Clark, K. B. (1988). Dynamic manufacturing: Creating the learning organization. Simon and Schuster

Hair, J. J., Sarstedt, M., Hopkins, L., \& Kuppelwieser, G. V. (2014). Partial least squares structural equation modelling (PLS-SEM) An emerging tool in business research. European Business Review, 26(2), 106-121.

Hair, J. F.,Black, W. C., Babin, B. J., \& Anderson, R. E. (2010). Multivariate data analysis (7 ${ }^{\text {th }}$ Ed.). Englewood Cliffs: Prentice Hall International Inc.

Hair, J. F., Black, WC., Babin, B. J., Anderson, R. E, \& Tatham, RL (2006), Multivariate Data Analysis 
INTERNATIONAL JOURNAL OF ACADEMIC RESEARCH IN BUSINESS AND SOCIAL SCIENCES

Vol. 9, No. 10, October, 2019, E-ISSN: 2222-6990 @ 2019 HRMARS

$\left(6^{\text {th }} \mathrm{Ed}\right)$

Hosseini, Z., \& Kamal, A. (2012). Questionnaire to Measure Perceived Technology Integration Knowledge of Teachers ( TPCK ). IJITCS Journal, (February), 1-

Holmes, C., \& Ferrill, M. (2005). The application of operation and technology roadmapping to aid Singaporean SMEs identify and select emerging technologies. Technological Forecasting and Social Change, 72(3), 349-357.

Human, G., \& Naudé, P. (2009). Exploring the relationship between network competence, network capability, and firm performance: A resource based perspective in an emerging economy. Management Dynamics, 18(1), 2-14.

Jagongo, A., \& Kinyua, C. (2013). The Social Media and Entrepreneurship Growth ( A New Business Communication Paradigm among SMEs in Nairobi ). International Journal of Humanities and Social Science, 3(10), 213-227.

Katou, A. A. (2009). The Impact of Human Resource Development on Organisational Performance: Test of a Causal Model. University of Macedonia, Greece. Behavioural and Applied Management, 10(3), 335-356.

Khalique, M., Isa, A. H. B. M. \& Shaari, J. A. N. B. (2013) 'Predicting the impact of intellectual capital management on the performance of SMEs in electronics industry in Kuching, Sarawak', The IUP Journal of Knowledge Management, 11(4),53-61.

Mahmud, N., \& Hilmi, M. F. (2014). TQM and Malaysian SMEs Performance: The Mediating Roles of Organization Learning. Procedia - Social and Behavioral Sciences, 130, 216-225. http://doi.org/10.1016/j.sbspro.2014.04.026

Martín-Rojas, R., Garcia-Morales, V. J., \& Bolívar-Ramos, M. T. (2013). Influence of technological support, skills and competencies, and learning on corporate entrepreneurship in European technology firms. Technovation, 33(12), 417-430

Miles, J. A. (2012). Management and organization theory: A Jossey-Bass reader (Vol. 9). John Wiley \& Sons.

Mitrega, M., Forkmann, S., Ramos, C., \& Henneberg, S. C. (2012b). Networking capability in business relationships - Concept and scale development. Industrial Marketing Management, 41(5), 739-751.

Ogunyomi \& Bruning, N. (2015). The International Journal of Human Resource Human resource management and organizational performance of small and medium enterprises ( SMEs ) in Nigeria, (September). http://doi.org/10.1080/09585192.2015.1033640

Olatunji, T. (2013). The Impact of Accounting System on the Performance of Small and Medium Scale Enterprises in Nigeria-A Survey of SME's in Oyo State-Nigeria. International Journal of Business and Management Invention, 2(9), 13-17.

Poutziouris, P., Wang, Y., \& Chan, S. (2002). Chinese entrepreneurship: the development of small family firms in China. Journal of Small Business and Enterprise Development, 9(4), 383-399.

Ratinho, T., Harms, R., \& Walsh, S. (2015). Structuring the Technology Entrepreneurship publication landscape: Making sense out of chaos. Technological Forecasting and Social Change, 100, 168-175. http://doi.org/10.1016/j.techfore.2015.05.004

Ritter, T. (1999). The Networking Company and Networks Effectively, 479, 467-479.

Ritter, T., Wilkinson, I. F., \& Johnston, W. J. (2002). Measuring network competence: some 
international evidence. Journal of Business \& Industrial Marketing, 17(2/3), 119-138.

Seleim, A., Ashour, A., \& Bontis, N. (2007). Human capital and organizational performance: a study of Egyptian software companies. Management Decision, 45(4), 789-801.

Saravanan, A., Gupta, P., \& Ghatak, S. (2008). SME Scenario around the World. Retrieved June, 20, 2012.

Sheehan, M., \& Shanahan, V. (2017). IHRD: investment in human capital and performance: Context, Processes and People. In Handbook of International Human Resource Development. Cheltenham, UK: Edward Elgar Publishing

Shipton, H., Dawson, J., West, M., \& Patterson, M. (2002). Learning in manufacturing organizations: what factors predict effectiveness?.Human Resource Development International, 5(1), 55-72.

Spiegel, M., \& Marxt, C. (2011, December). Defining technology entrepreneurship. In 2011 IEEE International Conference on Industrial Engineering and Engineering Management (pp. 16231627). IEEE

Siepel, J., Cowling, M., \& Coad, A. (2017). Technovation Non-founder human capital and the longrun growth and survival of high- tech ventures. Technovation, 0-1. http://doi.org/10.1016/j.technovation.2016.09.001

Sodri, A., Wahaba, I. A., \& Zarida, H. (2012). Foundamentals of entrepreneurship growth. Shah Alam, Malaysia: Oxford fajar.

Singh, A. S., \& Masuku, M. B. (2013). Fundamental of applied research and sampling techniques. Int J Med App/ Sci, 2(4), 123-124.

Swanson, R. A., \& Holton, E. F. (2010). Foundations of Human Resource Development. Berrettkoehler publishers Inc.

Thornton, S. C., Henneberg, S. C., \& Naudé, P. (2014). Conceptualizing and validating organizational networking as a second-order formative construct. Industrial Marketing Management, 43(6), 951-966. http://doi.org/10.1016/j.indmarman.2014.05.001

Torkkeli, L., Kuivalainen, O., Saarenketo, S., \& Puumalainen, K. (2016). Network competence in Finnish SMEs: implications for growth. Baltic Journal of Management, 11(2), 207-230. http://doi.org/10.1108/BJM-02-2015-0032

Torkkeli, L., Puumalainen, K., Saarenketo, S., \& Kuivalainen, O. (2012). The effect of network competence and environmental hostility on the internationalization of SMEs. Journal of International Entrepreneurship, 10(1), 25-49.

Tidd, J., Bessant, J., \& Pavitt, K. (2005). Managing innovation integrating technological, market and organizational change. John Wiley and Sons Ltd.

Wernerfelt, B. (1984). A resource-based view of the firm. Strategic management journal, 5(2), 171-180

Zainudin, A. (2015). SEM made simple: A gentle approach to learning StructuralEquation Modeling. Bangi: MPWS Publication Sdn Bhd. 